Европыһttps://inosmi.ru/politic/20191220/246481630. html

16. УНІАН (Украина): Палата общин парламента Британии одобрила соглашение о
Брекситеhttps://inosmi.ru/politic/20200110/246581939 .html.

\title{
THE TERMINOLOGY OF ECOLOGY IN FRENCH, ENGLISH, RUSSIAN LANGUAGES IN THE UN DOCUMENTATION: TRANSLATION ASPECT
}

\author{
Koroleva Svetlana \\ Doctor of Philology, Professor \\ of Linguistics University, Nizhny Novgorod \\ Malinovsky Maxim \\ DOI: $\underline{10.31618 / \text { nas.2413-5291.2020.1.56.239 }}$
}

\section{Abstarct}

The article is devoted to the problem of differentiation between justified and unjustified borrowings from English in Russian environmental term system. The article formulates a methodology of harmonizing ecological terminology. To do so we check if a borrowing has a synonymous traditional term.

Key words: ecological term system; the French language; the English language; the Russian language; adoption; assimilation; English borrowings.

Over the past 30 years, the terminology of ecology is of great interest to both ecologists and linguists as the globalization process has intensified. English is becoming the dominant language in many areas. This fact has an impact on the environmental science. Moreover English-speaking countries have made a significant contribution to its development [13]. Among significant papers published in this sphere over recent years, it is worth mentioning works 'Ecological term systems of French and Russian' (by N.I. Jabo), 'Establishment and development of the ecological term systems in the English language' (by E.A. Latyshevskaya), 'The functional model of a bilingual ecological thesaurus dictionary’ (by M.A. Kovyazina), 'Discursive structures of ecological themes in linguistic and legal aspects (by E.G. Hitarova) [1, c. 2-7].

Attention of Russian linguists studying environmental terminology systems is focused on the description of the actual state of ecological term systems, the methods and sources of their replenishment, the development of terminology classifications, methodology of harmonizing environmental terms and compiling environmental dictionaries, thesauruses and glossaries [1, c. 8-10].

However, the problem of non-English ecoterminology development within the frames of borrowing from the English language and without these frames has not been studied closely. The article deals with this problem in the aspect of justified and unjustified borrowings-terms in Russian ecoterminology.

As it is justly argued by A.N. Kamnev, until the 1990s most environmental terms in English, French and Russian languages were internationalisms, for example:

\section{- «Hydrometeorology»}

(Rus) гидрометеорология / hydrométéorologique / (Eng) hydrometeorology;

- «Ozone layer»

(Rus) озоновый слой / (Fr) couche d'ozone / (Eng) ozone layer [6, c. 169].
Nowadays internationalisms are being ousted by active English borrowings (either pure borrowings or calques), for example:

«Aftershok» (secondary seismic push, less intensity than the main seismic strike)

(Rus) афтершок / (Fr) shockafter / (Eng) aftershock;

«Upwelling» (meteorological process: deep ocean waters ascending to the surface)

(Rus) апвеллинг / (Fr) remontée d'eau / (Eng) upwelling [15].

Yet there is a big difference between Russian and French variants of openness to the influence of the English language. Today the French environmental terminology is not that much subjected to the process of borrowing from English as the Russian environmental terminology. In case of the latter, many of-borrowed terms are to be acknowledged unjustified, for example [7, c. 4]:

«Environmentalism» (a social ecological movement which spread in the 20th century in European countries aiming at strengthening environmental protection measures)

(Rus) энвайронментализм / (Fr) écologisme / (Eng) environmentalism;

«Recycling» (utilization of recycled raw materials and household waste)

(Rus) рисайклинг / (Fr) recyclage / (Eng) recycling [15].

The quality of being justified or unjustified does not belong to the system of ecoterminology, or on the process of borrowings, as it is. This quality is 'ascribed' by theory of borrowing according to the fact of presence or absence of semantic equivalents - terms with associated/synonymous/close meanings - in the system of the language [11, c. 38].

To differentiate between justified and unjustified borrowings of ecoterms in the Russian language we analyze the environmental terminology of the UN and UNEP [16], which is available on the official website of the United Nations in the section «Terminology» (UNTERM) [17]. 
A comparative analysis of documents in Russian and French brings into focus the fact that the Russian environmental terminological system is more open to borrowings from the English language. The terms which are widely used in the documents include: афтершок (aftershock), вейст-индекс (waste index), дефористация (deforestation), экологический мониторинг (environmental monitoring), рисайклинг (recycling), спрединг (spreading), фориок (foreshock), экологическая культура (ecological culture), экологический кодекс (environmental code), некк (neck), рuфm (rift)[3, с. 6-7].

In general, this phenomenon can be explained by the development of computer technologies and the Internet which revolutionized the spread and exchange of information. The amount of sources available for information study has increased by many times. One can see the reasons why the environmental terminology is so fragmented despite the fact that there is a number of requirements applied to borrowed terms formulated by D.S. Lotte [10].

Eight of the eleven terms cited are to be qualified as unjustified borrowings.

Six of the terms have semantically equivalent traditional terms: 'вейст-индекс' (waste index) is semantically equivalent to the traditional term 'индекс отходов' [14, с. 5], 'дефористация' (deforestation) to 'обезлесение' [4], 'рисайклинг' (recycling) - to 'переработка' [5], 'некк' (neck) - to 'жерловина' [18], 'рифт' (rift) - to 'разлом' [13].The term 'спрединг' (spreading) is partly adopted in the Russian language - this fact can be illustrated by the presence of the term in The Large Russian Encyclopedia [2]. Nonetheless, we consider that the descriptive translation 'разрастание океанического дна' could be a better option and would present the process clearly and help avoid confusion.

The term 'афтершок' (aftershock) is semantically equivalent to the traditional term 'повторный толчок'. The term connected with it by the subject area 'форшок' (foreshock) - hasn't got a semantically equivalent term yet but it is considered to be relatively easy to be made taking the connection with the other term into consideration. Two possible terms which we consider to be a better option is 'первый толчок' or 'предварительный толчок'.

The term 'экологический мониторинг' (environmental monitoring) can be called a justified borrowing as it's already adopted in the Russian language and got into the dictionary [9, c. 555]. Apart from it, it has a special semantic component if compared to its closest synonym 'наблюдение', comprising the meaning of not only observing some phenomenon but monitoring it all the time, analyzing the data and making suggestions on its basis.

The terms 'экологическая культура (ecological culture) and 'экологический кодекс' (environmental code) can be considered as justified calques due the presence of well-assimilated borrowings 'культура' (culture) and 'code' (кодекс) which can be found in various dictionaries and are used in many areas apart from ecology.
It is evident that the problem of harmonizing ecoterminology is very acute for the Russian terminology system.

So we conclude that the environmental terminology harmonization in the UN documents in English, French and Russian, should include differentiation between justified and unjustified borrowings and prescriptions concerning their usage. Unjustified borrowings should be replaced by traditional terms to observe norms of speech and principles of linguistic safety [8, c. 297-314].

Despite the fact that ecological term systems have been created mainly on the basis of Greek-Latin elements, and it would seem that mutual translating and understanding such terms may cause no difficulty for European and Russian languages, many cases of active and sometimes unjustified borrowings from the English language make the situation much more complicated. Excessive borrowings from the English language may cause deformity of a (national) linguocultural term system and lead to numerous communication discrepancies.

\section{Список литературы:}

1. Agranovskaya, A. (2016). Overview of Dissertation Studies in the Terminology of Ecology. [Electronic version]. Peoples' Friendship University of Russia Journal, N. 3, pp. 2-7.

$2 . \quad$ Big R R
https://bigenc.ru/geology/

3. Diakov, A., Deikina, S. (2014). English borrowing of the Semantic Sphere "Environment". [Electronic version]. Siberian University of Consumer Cooperation Journal, N. 10, pp. 6-7.

4. Efimov, A. (2020, April 2020). Deforestation is caused by the migration of Indo-Europeans, Nplus1. Retrieved June 10, 2020 from https://nplus1.ru/news/2020/04/07/forests

5. Hrapchenkova, I. (2015, April 2015). How to recycle plastic bottles in Russia, Recyclemag. Retrieved May 3, 2020 from https://recyclemag.ru/article/plarus

6. Kamnev, A., Kochurov, B., Istomina, E. (eds) (2018). English-Russian / Russian-English Environmental Science Dictionary. Moscow: Publishing House "National Education".

7. Kitova, I. (2015) The Issue of Translating English Terminology from the Standpoint of the Ecology of Language. [Electronic version]. Translation and Comparative Linguistics Journal, N. 11, p. 4.

8. Koroleva, S., Porshneva, E. (2019). Russian standarts of higher education (linguistics and translation): problems of linguistic security from the perspective of linguodidactics. [Electronic version]. Language and Culture Journal, N.48, pp. 297-314.

9. Kuznetsov, S. (2008). The Explanatory Dictionary of the Russian Language. St. Petersburg: Norint.

10. Lotte, D. (1982). Foreign terms and term elements borrowing and streamlining issues. Moscow: Publishing House "The Science". 
11. Marinova, E. (2013). Theory of borrowing in basic concepts and terms: dictionary-reference. Moscow: FLINTA: The science, p. 38.

12. Mashakaeva, E. (2012). The Role of Linguistics in Solving Global Environmental Problems. [Electronic version]. South Ural State University Journal, N. 25, p. 5.

13. Mihaylov, V. (2008, April 2008). Rifts of the Earth's crust and their impact on construction and operation of engineering structures, Cyberleninka. Retrieved April 22, 2020 from https://cyberleninka.ru/article/
14. Rachkov, V., Novichkova, G. \& Fedina, E. (1998). Man in a modern mechanized society: problems of development security. Moscow: Institute of Philosophy Russian Academy of Sciences.

15. Unterm.un.org: https://unterm.un.org/unterm/ 16.

Unepcom.ru: http://www.unepcom.ru/unep/unep-bodies/gc.html

17.

https://unterm.un.org/unterm/portal/welcome

Unterm.un.org:

18. Zaykov, V. (2007, July 2007). At the birthplace of the volcano, Gazetanu. Retrieved May 15, 2020 from http://www.uran.ru/gazetanu/

\title{
СПОСОБЫ СЕМЕНТИЗАЦИИ МЕТАФОР В АСПЕКТЕ ПРЕПОДАВАНИЯ РУССКОГО ЯЗЫКА КАК ИНОСТРАННОГО
}

Пузина Инна Викторовна

Магистрант

Оренбургский государственный университет

2. Оренбург

\section{METHODS OF SEMANTIZATION OF METAPHORS IN THE ASPECT OF TEACHING RUSSIAN AS A FOREIGN LANGUAGE}

\author{
Puzina Inna Victorovna \\ Master of Science \\ Orenburg State University \\ Orenburg
}

\section{Аннотация}

Статья посвящена одной из актуальных проблем обучения восприятия и понимания метафор русского языка в тексте иноязычными студентами - проблеме семантизации метафор. Приводятся различные способы семантизации русских метафор, которые иностранные обучающиеся могут встретить в текстах учебников по русскому языку как иностранному на разных этапах обучения.

\section{Abstract}

The article deals with one of the actual problem of interpreting metaphors of the Russian language in the text by foreign speakers - the problem of semantization of metaphors. Foreigners can meet different Russian metaphors in the texts of Russian as foreign language textbooks. The different methods of semantization of metaphors are described below.

Ключевые слова: семантизация; способы семантизации метафор; метафора русского языка; методика РКИ; работа над метафорой.

Keywords: semantization; methods of semantization of metaphors; the metaphor of the Russian language; the methodology of teaching Russian as a foreign language; work on the metaphor.

В процессе овладения русским языком иностранные студенты сталкиваются с проблемой различения и понимания метафор в тексте. При работе с материалом, содержащим образные средства, следует учитывать, что значения метафор русского языка иностранец воспринимает совершенно иначе, в связи с чем, требуется их объяснение и запоминание. Поэтому целью нашего исследования является определение способов семантизации метафор в аспекте преподавания русского языка как иностранного.

В словаре лингвистических терминов дается следующее определение термина семантизация: «Семантизация - выявление смысла, значения языковой единицы». Соответственно, способы семантизации - это пути раскрытия значения языковой единицы. Под способами семантизации метафор мы пониманием различные приемы выявления имплицитного значения метафор.
При выборе тех или иных способов семантизации метафор следует учитывать методические, психологические и лингвистические факторы. Методические факторы включают этап обучения, уровень владения языком, техническую обеспеченность учебного процесса. К психологическим относят возраст обучающегося и уровень языковых способностей. Лингвистические факторы выражаются в характере слов (абстрактные, конкретные, многозначные, служебные) и контрастивной ценности слов (то, что отличает слово от слова родного языка), а также рассматривают внутренние особенности слов, их системные свойства.[1, с.59]

За основу способов семантизации метафор нами были выбраны общеизвестные способы семантизации лексики.

Различают переводную и беспереводную семантизации. 